\title{
14. HRM as an emerging new managerial profession
}

\section{Paul Higgins, Ian Roper and Sophie Gamwell}

\section{INTRODUCTION}

Human resource management (HRM) is an emerging 'managerial profession'. Managerial professions are hybrid occupations claiming some attributes from traditional 'occupational professions' but also deviating from them on others. From classical studies it is acknowledged that there are tensions between managers and professionals (Weber, 1978): managers desire accountability to organizational objectives and professionals desire autonomy to pursue some 'higher' objective. However, the boundaries have never been fixed. In recent decades a number of authors have observed traditional professions becoming more accountable - and similar - to managerial sources of authority (Flynn, 1999; Exworthy and Halford, 1999; Dent and Whitehead, 2002). In contrast, HR practitioners could be said to be moving in the opposite direction: as a managerial function redefining itself into a profession.

This chapter will examine HRM as a managerial profession, identifying important tensions in the nature of work in this particular managerial function. In particular, four dilemmas are proposed which intersect the literature both on professions and on HRM. These dilemmas are: (1) the degree of autonomy that is appropriate - or possible - in dealing with various organizational stakeholder interests; (2) balancing the desire to have an influence on strategic issues while retaining a claim to organization expertise in core HR activities; (3) ascertaining the scope of discretion in the HR practitioner's expertise compared to its operational authority; and (4) whose interests does - or should - HR be working for?

In examining the four dilemmas the chapter makes an important contribution to the literature on professions and to the specific study of HR professionalization. In particular, evidence is presented from two contrasting national contexts: the United Kingdom (UK) and Hong Kong 
(HK). By considering the dilemmas in an East-West context, the chapter responds to concerns that comparative studies of new managerial professionalization are extremely rare (Brock et al., 2014), and to concerns that studies of the professionalization of HRM tend to focus on personnel management associations rather than on HR practitioners themselves (Farndale and Brewster, 2005). A comparison between HK and the UK is particularly informative because of the potential cross-fertilization of practices. In HK there are 'legacy' issues: the desire to match the perceived levels of influence achieved in the UK and the potential role for influencing HR professional practice in mainland China. In the UK there has been a reciprocal desire to learn from and adopt so-called 'turbo' HR practices from the East (CIPD, 2010).

The chapter proceeds as follows. First, it deals with the definitional issue of identifying what is meant by being professional, and how HR fits broadly into this. It then examines each of the four dilemmas in turn, reporting both on their theoretical foundations in the HR and professions literature and on their empirical manifestation. This rich combination of theory and evidence yields some fascinating results whose overall comparison and implications for HR, and other emerging professions, are duly considered in the conclusion.

\section{THE HR PRACTITIONER AS MANAGERIAL PROFESSIONAL}

The first issue to deal with is the definitional one of identifying what is meant by 'professional'. However, some further elaboration is required in order to identify the motive bases and resources potentially held by HR practitioners. The sociological analysis of the professions has shifted in emphasis over time (Evetts, 2006; Sciulli, 2005). The early focus was on what the core attributes of a profession might be, largely informed by structural functionalist perspectives and based on Anglo-American contexts (Abbott, 1988; Carr-Saunders and Wilson, 1933; Larson, 1977; Parsons, 1939). Burrage and Torstendahl (1990), for example, identify the core characteristics of being a professional as comprising a liberal non-manual occupation with monopoly control over labour-market supply, self-governance, specialized training that is also scholarly, control over entry via qualifications and of material and symbolic rewards for members based on the exclusive claim to social legitimacy. Some have questioned attempts at such narrow definitions (Evetts, 2006; Muzio et al., 2011), but it seems important for some form of minimum characteristics to identify any claim to professional identity to be available even if 
there may be differences between particular occupations and where a binary distinction is unrealistic, given the variety of occupations claiming some form of professional status, with credible claims for wider social legitimacy for doing so.

Moreover, critics of the trait approach invariably end up relying on some version of it to distinguish between, for example, organization professions and occupational professions (Evetts, 2013) or corporate professions and collegiate professions (Muzio et al., 2011), and there are certain features of established professions that can immediately screen out new contenders - the presence of licensure being one such example (Wiley, 1995). In neither HK nor the UK does the practice of HR require a licence. Neither would expulsion from the governing body prohibit an individual from practicing HR (Fanning, 2011). According to Gilmore and Williams (2007) licensure (that is, the permission to implement specific actions that are disallowed to other actors; Evetts, 2006) distinguishes legalized professions from commercialized ones when certification (that is, the use of a particular professional title limited to individuals who have met specified standards for education, experience and examination performance; Lengnick-Hall and Aguinis, 2012) will suffice. However, because HR certification has no legal status, its impact rests upon its value among relevant stakeholders: practitioners, organizations and society.

The legalistic shortcoming leaves the dilemma of mandate, which goes further and implies the right to prescribe how others must act ('for their own good') (Pfadenhauer, 2006). This can occur both within organizations and beyond them (that is, socially) to reflect the fact that professionals might be said to have legally enshrined licence to operate, but do not necessarily have exclusivity over an activity. As Bailey (2011) explains, 'public policy' directly affects the HR practitioner because it provides one of the means by which they can demonstrate institutional coercion by ensuring that any corporate action is conducted within the boundaries of the law. However, the danger with this 'gatekeeper' source of professionalization is that the state rather than the profession is seen to control the work of the practitioner (ibid.), which produces an interesting development on the tension that is usually identified between occupations and organizations (Noordegraaf, 2011). It also makes assumptions about the role of the state as neutral arbiter between 'labour' and 'capital' at societal level, in establishing the parameters of the practitioner at workplace level, whereas its scope and orientation towards the various competing interests varies considerably internationally, as reflected in the institutionalist literature (Streek, 2011). 
While much remains unresolved on the definition issue, the focus has shifted to an interest in the process of professionalization; either as a cultural manifestation of class identity in continental Europe (Sciulli, 2005) or, less successfully, as the attempt to bolster certain occupations through 'credentialization' - achieving only the ability of raising barriers to entry (Vaisey, 2006). This broad area of enquiry has continued in the examination, in contemporary scenarios, of how certain occupations are able to enhance their status, legitimacy and, thus, their claim to becoming professions (Evetts, 2013). Another emphasis in the study of professions and professionalism has been on how professionals interact with clients and other working colleagues with lower status. The focus here has been on problematizing professional power; which (implicitly) is the substance of Goffman's (1961) classic study of the asylum and also the essence of what more recent Foucauldian approaches refer to as the 'performativity' of professionals at work (Dent and Whitehead, 2002; Grey, 1998).

This more negative emphasis of professionals at work has been tempered more recently by a more neutral tone. This has partly been prompted by the observation that professional work has found itself, particularly in the public services, subject to much greater pressure to subordinate attributes of professionalism (autonomy, exclusivity) to the powerful interests of markets, in the form of clients-redefined-ascustomers (DuGay, 1996). Thus, if the critical study of professionalism in the 1960s and 1970s revealed the role played by professions in the pursuit of class privilege, when compared to the more visible actions of trade unions, this distinction became more blurred with the increasingly 'professional' profile of trade union membership from the 1980s onward (Millward et al., 2000). It was now professions under pressure (Perkin, 2002).

It is in this context that we see the rise of new managerial professionals as a hybrid development, where HRM is an ambiguous contender for a rising category within managerial professions. Evetts (2013: 788) distinguishes between 'traditional' professions (which she terms 'occupational professionalism') and 'managerial' professionalism (which she terms 'organisational professionalism'). The newer organizational professionals are defined by the following:

- Discourse of control is managerial (rather than within professional groups).

- Authority is rational-legal (rather than collegial).

- Work procedure is standardized (rather than discretionary).

- Authority structure is hierarchical (rather than trust-based). 
- Accountability is to external regulation (rather than via ethics codes).

- Mode of organization is Weberian rather than Durkheimian.

These characteristics constitute a stark departure from the established professions in terms of power resources (in relation to managerialism), and the residual claim to professionalism would seem to be based on status (the ability to attract membership), claims to expertise (with varying degrees of exclusivity) and the existence of a collective body to promote common interests. Where does the HR professional sit within this?

Firstly, it is important to acknowledge that the status of HRM has been enhanced by its apparent 'rebranding' from the 1980s onward from its previous guise as 'personnel'. The discourse of HRM emerged in a climate that promoted management ideologies that proactively endorsed free markets, deregulation and unitarist approaches to employment relations (MacInnes, 1987). So, by association, HRM is often defined in terms of how it fits within this contemporaneous entrepreneurial climate, whereas personnel management is retrospectively defined through its association with a climate where managements operated under pluralist assumptions and were therefore less able to act assertively.

Numerous writers have examined this journey as being pioneered in the US where HRM became a more strategic, proactive managerial function aiming to 'leverage' the distinct human contribution to competitive advantage; the so-called resource-based view (Allen and Wright, 2007; Boxall and Purcell, 2011; Legge, 2005). Importantly, however, from the perspective of a professionalization agenda (Larson, 1977) the rise of HRM offered the promise that the function could move towards a strategic rather than a supporting organizational role, and thus ensure a firmer professional jurisdiction for its services through finally establishing the clarity and then the legitimacy of its practice (Gilmore and Williams, 2007). According to this position, rather than necessarily representing a threat to professions, managerial authority within organizations can also be a source of power (Noordegraaf, 2011). As Brint (1994: 73 in Muzio and Kirkpatrick, 2011: 392) explains, for many 'corporate' professions, controlling 'high value added applications' within organizations may be equally, if not more, important for enhancing status than is closure in the labour market. Successful professions are often those that achieve 'diffuse legitimacy' over the performance of strategically important tasks within organizations (ibid.).

Secondly, we could judge the status of HR as a profession on the basis of the profile of representative bodies for HRM internationally. On this, a 
varied picture emerges. If a useful proxy for status is membership levels, then HR would seem to be much more entrenched in what we might categorize as liberal-market economies (Hall and Soskice, 2001). Alternatively, if a useful proxy for status is exclusivity, then rising numbers of members could equally be seen as diluting institutional reputation.

Worldwide the HR profession is represented by the World Federation of People Management Associations (WFPMA) with a global affiliate membership of around 600000 in 2014. Membership of constituent regional affiliates tends to follow some consistent patterns but also some internal diversity. Thus, Africa has low membership levels, which might reflect stages in economic development, though this would not explain the low membership levels in South Africa (1800). North America shows high levels of absolute membership in the USA (Society for Human Resource Management, SHRM, 275 000) and Canada (Canadian Council of Human Resources Associations, CCHRA, 15 000). Europe would seem to be split between those countries most closely aligned to corporatist 'coordinated market economies' (Hall and Soskice, 2001) and others. Thus, the Chartered Institute of Personnel and Development (CIPD) in the UK claims 135000 members, whereas the Austrian Centre for Productivity and Efficiency (ÖPZ) in Austria has only 400 members, all corporate affiliates rather than individuals. Germany (the Deutsche GesellschaftfürPersonalführung eV, DGFP) similarly only has 2500 members. Finally, the Asia Pacific region claims 15000 Australian Human Resources Institute (AHRI) members in Australia, but scarce representation in China - though the Hong Kong Institute of Human Resource Management (HKIHRM) in HK claims 5000 members; see Table 14.1.

Thirdly, there is an implicit parallel with Muzio et al.'s (2011) study of the professionalization of management consultancy in that professions have historically had a distinct national focus, with their jurisdictions generally coinciding with national boundaries. However, as per the management consultancy case, the HR profession displays a distinct international dimension and vocation. At its simplest level, this is realized through membership of a global umbrella body, the WFPMA, which coordinates such international initiatives as congress, research and networks between national and regional-level associations. However, unlike the situation for management consultancy this progress has not yet gone as far as the development of international qualifications, codes of practice and competence frameworks. Instead, such WFPMA coordination indicates how new professional associations are pursuing their traditional objectives and performing their traditional functions (such as lobbying, certification and regulation) but this is increasingly occurring "within 
JOBNAME: Wilkinson PAGE: 7 SESS: 3 OUTPUT: Thu Nov 19 10:55:35 2015

292

Perspectives on contemporary professional work

Table 14.1 HR professional bodies: international selection

\begin{tabular}{|c|c|c|}
\hline Country & Organization & $\begin{array}{c}\text { Number of } \\
\text { members (2014) }\end{array}$ \\
\hline Austria & $\begin{array}{l}\text { Austrian Centre for Productivity and Efficiency / } \\
\text { Österreichisches Produktivitas-und } \\
\text { Wirtschaftlichkeits-Zentrum }\end{array}$ & 400 \\
\hline Australia & Australian Human Resources Institute & 15000 \\
\hline Canada & $\begin{array}{l}\text { Canadian Council of Human Resources } \\
\text { Associations }\end{array}$ & $15000 *$ \\
\hline France & $\begin{array}{l}\text { Association Nationale des Directeurs des } \\
\text { Ressources Humaines }\end{array}$ & 5000 \\
\hline Germany & Deutsche GesellschaftfürPersonalführung eV & 2500 \\
\hline India & $\begin{array}{l}\text { National Institute of Personnel Management } \\
\text { (NIPM), India }\end{array}$ & 12000 \\
\hline Kenya & Institute of Human Resource Management & 1834 \\
\hline Hong Kong & $\begin{array}{l}\text { Hong Kong Institute of Human Resource } \\
\text { Management }\end{array}$ & 5000 \\
\hline Japan & Japan Society for Human Resource Management & 350 \\
\hline South Africa & Institute of People Management & 1800 \\
\hline UK & Chartered Institute of Personnel and Development & 135000 \\
\hline USA & Society for Human Resource Management & 275000 \\
\hline
\end{tabular}

Sources: Membership data taken from World Federation of People Management Associations, http://www.wfpma.com/members/list\#quicktabs-tab-1-0 (accessed November 2014).

transnational markets and international divisions of labour' (Evetts, 1995: 772). There is no evidence of significant mutual recognition of professional membership standards among national bodies.

Depending on the institutional setting upon which professionalization is possible, HRM is generally in a position to make a claim to be an emerging managerial profession. It has a body to represent its interests at numerous national, regional and international levels, can claim an area of specialist expertise - in many cases requiring de facto entry requirements and ethical codes controlled by the national body; yet is 'organizational' in its claims to authority. However, there are also some particular issues relating to 'what HRM does' that make this managerial profession worthy of particular scrutiny. Four dilemmas are identified, which highlight the sometimes ambiguous nature of HRM as a profession which intersects both the literature on professions and debates concerning the desired role and purpose of HR. 


\section{FOUR DILEMMAS}

The first dilemma relates to the scope of professional autonomy when faced with challenging ethical demands of an employer in relation to its workers. The second dilemma is: what balance should HR practitioners strike between competently administering core HR tasks to secure the trust of organizational clients, and making strategic contributions that demonstrate HR's unique and critical importance? The third dilemma is that HR must not only identify a key business problem but also highlight how its expertise alone can solve it (Wright, 2008). Finally, whose interest is HR working for, or should it be working for? In examining the four dilemmas the chapter draws upon survey evidence collected from over $1000 \mathrm{HR}$ practitioners in HK and the UK as well as insights from nine elite interviews with offers and members of the two respective people management associations and six organizational case studies of HR in practice.

\section{Dilemma 1: What Is the Scope for Professional Discretion in HRM?}

The first dilemma relates to the incompatibility of matching the professional's traditional claim to autonomy and unitarist (Fox, 1966) demands placed on the HR practitioner in many organizational contexts for the unqualified pursuit of executive management objectives. As a profession, this could be seen as relinquishing aspects of legitimacy in terms of independent expertise (Kochan, 2007), although others question whether many organizations fit this ideal. This is a conclusion drawn by Friedson (1986) in his questioning of the thesis that if professionals become employees (or are already) then they lose their independence and so become proletarianized, like the artisans before them.

Nonetheless, there could still be a difference between professions in the extent to which they demonstrate independence. On this point, Fanning (2011) questions whether HR is similar to other professions within the organization that serve the company but also are held to the standards of practice of their profession, such as lawyers and accountants. Or are they general managers who should follow the needs of the business without regard to their profession's code of ethics (ibid.)? If HR is a profession then HR practitioners should be able to refuse to do things that the senior management team of the organization ask them to, if they go beyond accepted HR standards (in the same way that legal or financial experts might) (ibid.). In the conventional HRM professional-line manager relationship the HR practitioner is usually assumed to have the authority to advise the line manager on aspects of employment law and 
its impact on the employment contract (Gold and Bratton, 2003). What about when it comes to challenging senior managers?

Here, it is interesting to note that a detailed comparison of the professional standards documentation of the CIPD and the HKIHRM points to a largely shared normative vision for HR theory and practice, centred on a combination of knowledge and behaviours (Higgins et al. 2014), but which differs slightly on the question of independence. Whereas the CIPD's behaviour standard includes a component entitled 'courage to challenge' no such element exists explicitly in the HKIHRM approach. Although typical cultural explanations emerge at this point such as differences in Hofstede's (1984) power-distance cultural dimension (UK low, HK high) and the influence of the Confucian heritage tradition in HK (Yuan, 2013), one has to be careful not to too casually imply that Chinese people are inherently unitarist in orientation. In the case of the CIPD, the challenge element stresses the importance of all HR practitioners showing 'the courage and confidence to speak up skilfully, when challenging others even when confronted with resistance or unfamiliar circumstances' (CIPD, 2012a). At the highest level of competence it further involves practitioners 'taking a highly visible stand to progress a disputed issue or ethical dilemma for the benefit of the organization, despite significant opposition and personal risk' and making 'unpopular or controversial decisions when necessary as a senior representative of the organization or human resources' (ibid.). Interestingly, the first of these standards encourages HR professionals to align their practice with positive outcomes for the organization rather than in line with professional ethics. This is important because it supports the view that organizational priorities, rather than a set of professional ethics outside the organization, are critical to the performance of HRM.

In considering the willingness of respondents to 'challenge' other organizational stakeholders on HR matters, the survey included three questions adapted from the CIPD's behaviour standard which asked both UK and HK respondents to state their propensity to challenge the views of senior managers, middle managers and employees. The results from this exercise are provided in Table 14.2. It can be seen that the data largely follow the expected trend, with the mean HK respondent challenge scores statistically lower than the UK ones $(p=0.000)$, having assumed equal variances at the 0.05 threshold for significance. Moreover, practitioners of higher membership status tend to be more willing to challenge the views of employees compared to those of middle managers and - even more markedly - the views of senior managers. A couple of anomalies materialize, however, when one hits the higher levels of membership status. For instance, HKIHRM fellows claim to be able to 
challenge everyone equally (4.83). Meanwhile, CIPD members and fellows both claim to demonstrate a marginally higher willingness to challenge middle managers over employees.

Table 14.2 HR practitioners' propensity to 'challenge different stakeholders on HR issues' $(1=$ never, $5=$ always $)$

\begin{tabular}{lccc}
\hline $\begin{array}{l}\text { 'I have the courage to } \\
\text { challenge ...' }\end{array}$ & HK mean & UK mean & $\begin{array}{c}\text { Mean } \\
\text { difference }\end{array}$ \\
\hline Senior managers & 3.64 & 4.32 & 0.672 \\
Middle managers & 3.83 & 4.48 & 0.649 \\
Employees & 3.92 & 4.48 & 0.560 \\
\hline
\end{tabular}

At base, such an extension of the ethical role has affinity with the stewardship principle of the CIPD's (2012b: 4.1) code of conduct which stipulates that practitioners should challenge others if they suspect unlawful or unethical conduct or behaviour. The corresponding statement in the HKIRHM (2000: 6) code stipulates that 'where corruption, fraud or malpractice of any kind is suspected within their own organization or among fellow professionals, members are advised to seek advice from or report to the appropriate authority'. Further on the issue of autonomy, the HKIHRM's (2000) code explains that 'HR professionals should communicate organizational values and standards, as well as monitoring and enforcing the standards within the organization' (HKIRHM, 2000: 3). The equivalent principle in the CIPD's code (CIPD, 2012b: 1) is to ensure that practitioners 'promote appropriate people management and development practices to influence and enable the achievement of business objectives'.

In both HK and the UK, then, practitioners and their professional associations do place emphasis on professional discretion, albeit the articulation of this varies between the two economies and between junior and senior practitioners. In line with more unitarist values, the CIPD links the idea of 'challenge' to organizational rather than professional standards. This moves HRM away from the territory of a traditional profession and towards being a managerial profession with its allegiance more closely tied to the firm than to any set of professional standards or ethics divorced from the organizational context. Meanwhile, the status differentials on the willingness of HR practitioners to challenge colleagues on HR issues corresponds with more general fears that HR is 
getting too close to business leaders and their modus operandi (Marchington, 2015).

\section{Dilemma 2: Is HR being Fragmented and Does It Matter?}

The second dilemma concerns the role ambiguity between HR proving its effectiveness through getting the basics of HR right (Gilmore and Williams, 2007), making a strategic contribution (Brint, 1994), and the false promise that a more strategic orientation would prevent HR fragmentation (Caldwell and Purcell, 2007). Similarly, while Marchington's (2015) critique of 'where HRM is going' is directed more at who it is claiming to work for (see dilemma 4), he does make a strong point, along the way, about HR losing much of the basics in its obsession with 'looking upwards'.

The empirical evidence is interesting in this regard. Survey participants were asked to indicate the extent to which they perform $26 \mathrm{HR}$ activities in their work (on a scale of $1=$ never perform function, $5=$ perform function all the time). The scope of the activities considered formed part of an inventory design whose scales and items corresponded to different levels of professional membership amongst both the CIPD and HKIHRM. This structure provides an important means to test the credibility of the standards when professional membership status is related to claimed HR knowledge (that is, the higher the membership status, the more the professional knowledge). At the same time, the scales and items can be organized thematically depending on the particular standards and expectations of the qualifying institutes. Based on the latter interpretation, the operationalization of the professional standards documentation of the CIPD and the HKIHRM reveals that five themes of HR practice are ultimately prioritized. These can be simply expressed as: professional, strategy, communication, administration and technical responsibilities.

Professional activities such as 'ensuring legal/regulatory compliance', 'keeping up to date with best practice HR' and 'acting with integrity' ranked highest for both sets of respondents (see Figure 14.1). Second on the list of behaviours that HK-based practitioners spend most of their time on is the undertaking of administrative practices (such as to 'maintain administration associated with HR', 4.02) followed by communication (such as the 'need to establish mechanisms for effective communication with HR service users', 3.89), strategic activities (such as 'my work requires me to make strategic decisions', 3.70), and finally technical practices (for example, mainly required to apply basic HR skills at work, 2.99). The respective thematic order and average overall score for UK respondents are as follows: professional (4.24), communicator 
(3.86), administrator (3.85), strategist (3.80) and technicist (2.55). These findings are consistent with other studies (Brown, 1981; Industrial Relations Services, 2004) which also fail to indicate the widespread HR practice of strategic over administrative activities. At the same time, although the two sets of results may reinforce the view from those commentators who seek to reform the identity of the HRM discipline away from a reactive transactional support activity into a proactive strategic function, three points are worth bearing in mind.

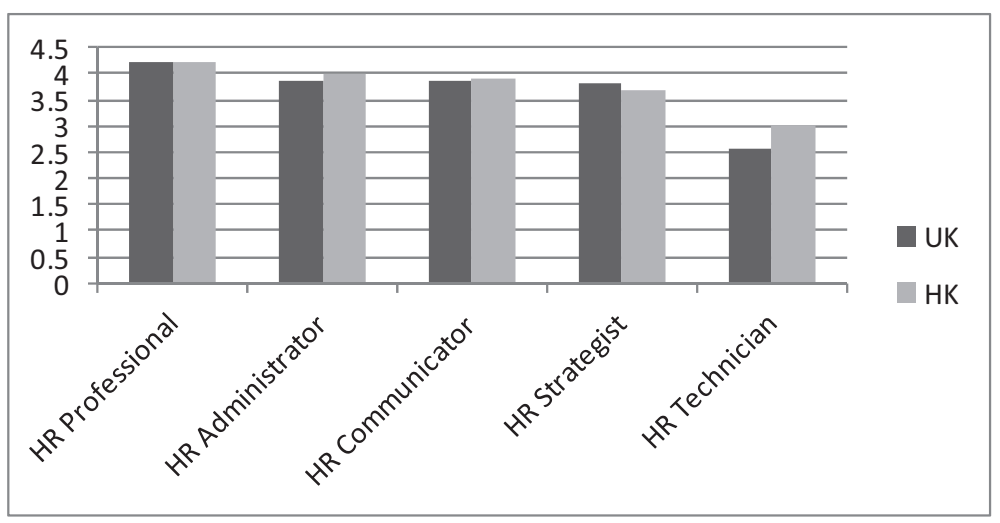

\section{Figure 14.1 Thematic HR behaviours}

Firstly, the structure of the HR profession means that not all practitioners are required to perform strategic functions in their work. In the case of the HK sample, for instance, FIHRM members claim greater strategic practice than MIHRM members, who in turn claim greater strategic behaviour than Associate ones. Moreover, whereas FIHRM members yield greater strategic and communication influence and lowest administrative and technical responsibility, virtually the opposite is recorded of Associate-level members. Once again, this finding is in line with the developmental objectives of the CIPD and HKIHRM and represents a technical advance on those studies that do not differentiate respondents in this way. Secondly, reassurance should be taken from the finding that the 'professional' domain of HR practice scores so highly, across all membership bands. Given the professionalizing objectives of the CIPD and the HKIRHM this attribute could be more clearly promoted as a core value.

Thirdly, in both economies HR practitioners professed least competence with data, financial information and budgeting. Fewer than half of HK HR professionals claimed to understand financial information (43 
per cent) compared with just over half of UK participants (55 per cent). Slightly more respondents in both economies said that they were able to manage the HR budget (UK $=61$ per cent, $\mathrm{HK}=56$ per cent). Despite HK participants' lack of confidence in relation to financial information, many more participants claimed to understand data analysis, with 61 per cent of HK HR professionals claiming this skill, compared with 53 per cent in the UK. These results are very interesting. According to Van Buren et al. (2011: 210-211):

the definition of 'strategic' comes from outside the function, and HRM thus seeks to make itself strategic by seeking to accomplish goals thought to be valuable to the organization. In this way HRM runs the risk of becoming tautological; companies that are financially successful become the exemplars of good HRM practices and those HRM practices are then deemed to be 'strategic' because their HRM practices were believed to have contributed to financial success.

A high degree of convergence between UK and HK respondents was observed in the confidence expressed in HR-related activities, with similar issues being ranked low (finance and data management issues), suggesting that HR practitioners struggle to speak the language of business.

As a further consideration of the extent to which HR practitioners must balance a strategic role with a core basic administrative competence, participants were asked to indicate where decisions on 14 strategic decisions are made within their organization. Of the five options offered, the main responses provided by participants were: 'senior management decides', 'HR has main responsibility' and 'jointly decided by HR, senior management and departmental management'. Taking the three most important responses only, the results reveal that for both the UK and HK respondents HR tends to take strategic decision-making responsibility for job design and employment contracts, work-life balance policy, and equality and diversity policy. Thereafter, UK respondents indicate that HR has main responsibility for consulting and negotiating with trade unions. Thirdly, the issues of employee engagement, staff planning and talent management, and performance measurement tend to be jointly decided or HR-responsible for both UK and HK respondents.

Meanwhile, the issues for which the senior management team tends to take a more influential role in decision-making are also fairly similar across the two sets of respondents, with organizational development, outsourcing of in-house activity, change management and employer branding scoring highly. Hence, for a large proportion of the issues the tendency is fairly similar for both UK and HK respondents. The minor 
differences include health and safety and risk assessment, which tends to be a more HR or operational issue in the UK compared to the more HR or jointly decided tendency of HK organizations. Likewise, pay grading structure and employer branding tend to be given more strategic priority in the UK compared to HK, where they are typically HR or jointly decided.

In summary, then, the survey evidence on strategic versus core administrative competence suggests that HR practitioners perform a variety of functions that capture both strategic and administrative elements but that these responsibilities are mediated by the status of the practitioner. In other words, not all HR practitioners are necessarily required to perform strategic functions in their work and such variety seems to be being increasingly reflected in the training that they are provided and on their professional career ladders. In many respects, such opportunities are being provided by the two professional institutes in the form of the CIPD's professional map and the HKIHRM's career ladder. The bigger question is what impact is this having on the status of HR. While HRM lacks licensure power socially, as far as its organizational power is concerned, it is seen to hold strategic importance on such core HR activity as job design and employment contracts, work-life balance policy, and equality and diversity policy. In contrast, it exerts much less power in the determination of such strategic issues as organizational development, outsourcing of in-house activity and change management.

\section{Dilemma 3: Does Devolving HR Decision-Making Lose Influence for HR?}

This leads to a third dilemma, an extension of the dilemma classically identified by Legge (1978), which relates to HR having competence in specific organizational issues but rarely being in the position of authority to use it, with much of the expertise that might be attributed to HR practitioners being devolved to line managers. As noted, the most influential model within the HR practitioner community for the reshaping of the HR profession in order to enhance its legitimacy has been the Ulrich model (Ulrich, 1998). The Ulrich model proposes a range of demarcated core activities in which HR possesses competence. It seemingly stratifies the HR function, with 'HR business partner' and 'change agent' roles operating at a strategic level, below which sits 'administrative expert' operating at a transactional level, and then the role of 'employee champion' seemingly operating as a value-set spanning all activities. Caldwell (2003: 1003), however, is not alone in challenging 
this, suggesting that 'Ulrich's prescriptive vision may promise more than HR professionals can ever really deliver'.

The attempt to shift the profile and status of HRM has some implications. The shift from HRM's prior position, with its reputation associated with a more transactional activity to its aspired-to new role of being an insightful 'strategic business partner', is a bold move with some unresolved issues. Most significantly, while these moves signal a clear intention to shift the profession closer to the source of legitimate decision-making power in organizations (employers, senior executive management), it does so by challenging two other elements associated with professional power in organizations. Thus, the knowledge and skills base of the HR practitioner is being moved away from the core competences traditionally associated with the function, and the focus of the normative content of the traditional notion of (relative) independence - who the HR practitioner should represent - is being redefined. Furthermore, it is unclear to what extent this move is in line with the existing experience and future aspirations of the HR practitioners the CIPD seeks to represent.

While there is broad consensus as to the broad boundaries of what constitutes HR in relation to other managerial functions, there has been a shift in emphasis away from the transactional activities (payroll, recruitment, selection, training, discipline, and so on), toward the role of advising and supporting line management in their delegated HR role, to being of value through the promotion of strategic policy to realize enhanced employee performance towards organizational goals (HopeHailey et al., 2005). In the most recent extension of this, the CIPD is now aiming to promote the role of strategic HR as being driven by insightful leadership. However, part of the mission to be strategic has required the HR practitioner to relinquish operational activities and delegate to line management, leading to some questioning whether line managers want these responsibilities and/or resent the standardization of people management activities from HR (Bach, 2005). Arguably, all of these shifts represent an interesting paradox in relation to HRM's position as a profession, and it is one mirrored by the strategic orientation of both the CIPD and the HKIHRM. The paradox is that while the position of HRM has grown in terms of influence - as measured by the number of practitioners and presence within UK firms (Kersley et al., 2005) - it has arguably done so at the cost of relinquishing attributes and power resources associated with expert power. Thus, the increased - if marginal - devolution of decision-making of key HR decisions to local managers observed in the UK between 2004 and 2011 (Van Woonroy et al., 2013: $52-53)$. 
Traditionally, a monopoly over a type of work gives an occupation the exclusive right to perform specified tasks and functions (Greenwood, 1957). However, in the case of HR its traditional remit - resourcing, learning and development, relations and reward - is being devolved to the line management. The danger with this approach, as Renwick (2003: 276) notes, is that it could contain 'the seed of HR's own redundancy if they lose all control over operational HR knowledge'.

Participants were given 14 operational responsibilities and asked to identify where responsibility resided in their organizations. By far the two most popularly selected response categories were: 'HR has main responsibility' and 'the operational department has main responsibility'. The other three options comprised: 'largely outsourced', 'we do not do this activity' and 'don't know largely excluded'. The distribution of the share of responses for the two most popular categories for UK respondents is provided in Figure 14.2 and for HK respondents in Figure 14.3.

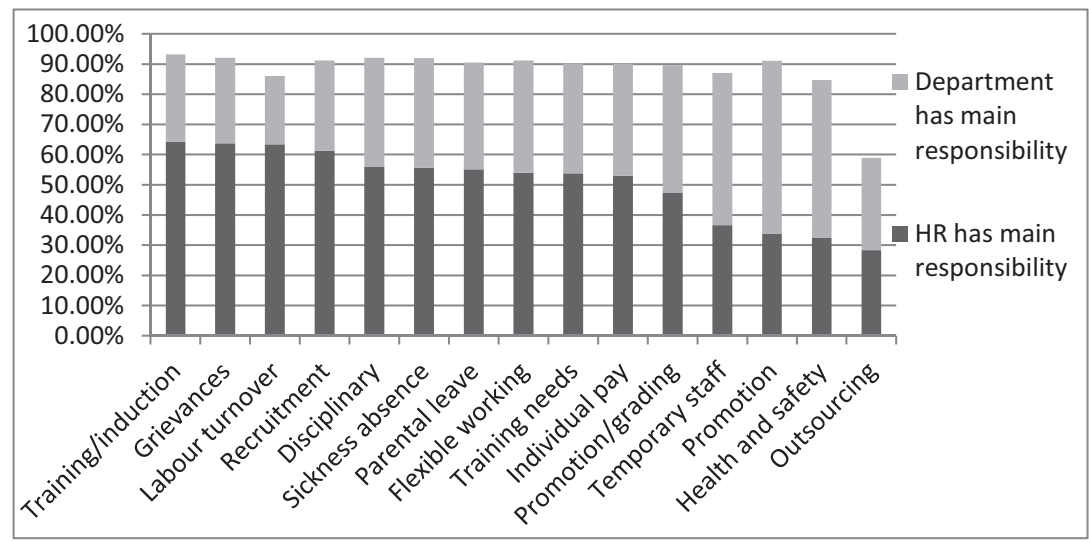

Figure 14.2 Main sources of operational decision-making, UK organizations

For operational responsibility, both HK and UK respondents explained that in their organizations HR made independent decisions on the tasks of monitoring labour and staff shortages, staff sickness absence, staff induction and training, staff complaints and grievances, and recruitment of new staff. In contrast, departmental responsibility tends to be taken on parental leave requests, health and safety, training needs analysis, individual pay issues, and flexible working requests. The major difference between the two samples concerns responsibility for health and safety, 
which is the most operationally determined UK issue, whereas in HK organizations it tends to be undertaken by HR.

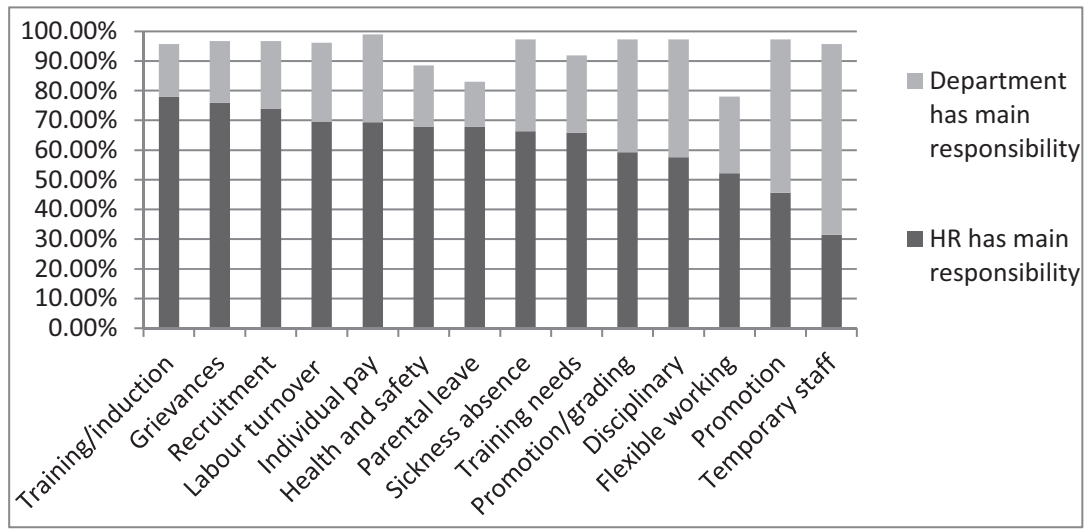

Figure 14.3Main sources of operational decision-making, HK organizations

Concerns that HR practitioners are architects of their own redundancy by a process of devolving increasing responsibility for HR matters to line managers (Sanders and Frenkel, 2011) are not entirely borne out in this study. Instead, the evidence suggests that HR remains involved in most operational decision-making, especially in HK where at least two-thirds of HR practitioners said their department retained responsibility for 11 of the 14 activities that formed part of the survey. Whilst this figure is much lower for the UK - two-thirds of respondents reported that HR departments were responsible for only around four of the areas - this still constitutes significant HR involvement in operational decision-making.

Practitioners were also asked about a range of HR activities, from resourcing, reward, training, and management development issues, through to employee relations issues (see Figure 14.4 and Figure 14.5). For each issue they were asked about their balance of experience and knowledge, capturing the issues where formal professional training has or has not occurred and matching to the opportunity to practice.

As might be expected, the most frequent response for all issues is of 'an ideal mix' and the issues are spread across all types of activities (the highest-ranked issues are recruitment and selection, and consulting and communicating with staff, both at 77 per cent. However, there are also issues where this perception of 'balance' is only marginal. The issue that stands out on this is union negotiation, where there is a fairly even distribution of response categories. This is likely to reflect the high 
proportion of workplaces without unions (from the sample, 38 per cent of UK workplaces and 8 per cent of HK workplaces were unionized).

When ranking these various issues, some common patterns emerge between practitioners in the UK and $\mathrm{HK}$ but also some interesting differences. For example, both sets of respondents ranked recruitment and selection, and workforce consultation, in their top four. Alternatively, whereas UK practitioners had the best knowledge-practice combination in staff discipline and performance management, the other two highestranked issues for HK practitioners were pay and benefits, and employment law.

In this category of response, the opportunity to impart the knowledge gained through professional development programmes is not being fulfilled in the workplace. However, more disparity was identified between the UK and HK cohorts. In the UK these issues were union negotiation (27 per cent), employer branding ( 26 per cent) and workforce planning (24 per cent), whereas in HK the issues were equality issues (33 per cent) and workforce planning (32 per cent).

The activities that were being carried out by practitioners with what felt like inadequate theoretical knowledge, again, varied between the two cohorts. Common to both was workforce planning (18 per cent of UK respondents, 21 per cent in $\mathrm{HK}$ ), but there was disparity on the rank order of other issues. In the UK other areas where knowledge was thought to be inadequate was on pay and benefits (18 per cent) and employer branding (16 per cent), whereas in HK the other stand-out issue was consulting with staff ( 23 per cent).

For the most part - as might be expected - this category attracted the fewest responses. However, for some issues this was not the case. One matter that particularly stands out is union negotiation, with 23 per cent of UK respondents and 43 per cent of HK practitioners fitting into this category. The issue of employer branding clearly had little resonance in HK where, at 28 per cent, 'no experience or knowledge' was the most frequent response, though 18 per cent of UK practitioners also responded this way.

Taken as a whole the results suggest strengths in the issues around the broad areas of 'people resourcing', but lower levels of competence on issues of employee relations. Thus, there are strengths on individual aspects such as dealing with recruitment, employee performance and disciplinary issues, but knowledge gaps on the more collective issues of pay systems, union negotiation (which in HK is paralleled by 'staff communication' and 'engagement'). An outlier to all of this was the apparent gap in knowledge on the issue of employer branding and the implications of HR practice on external reputation. 


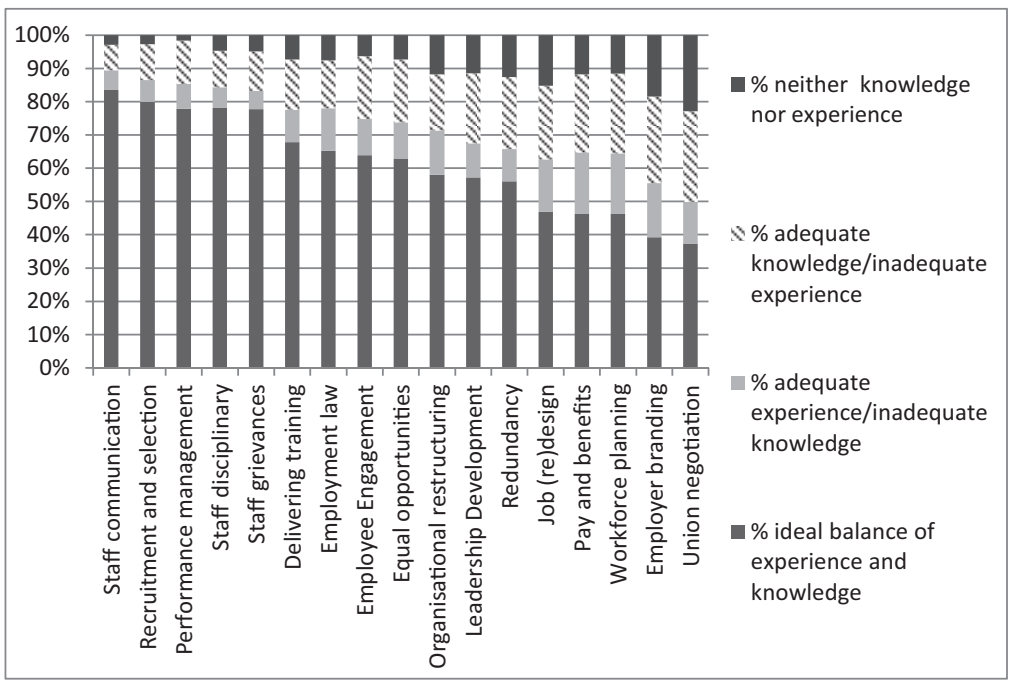

Figure 14.4 Balance of HR knowledge versus experience, UK respondents

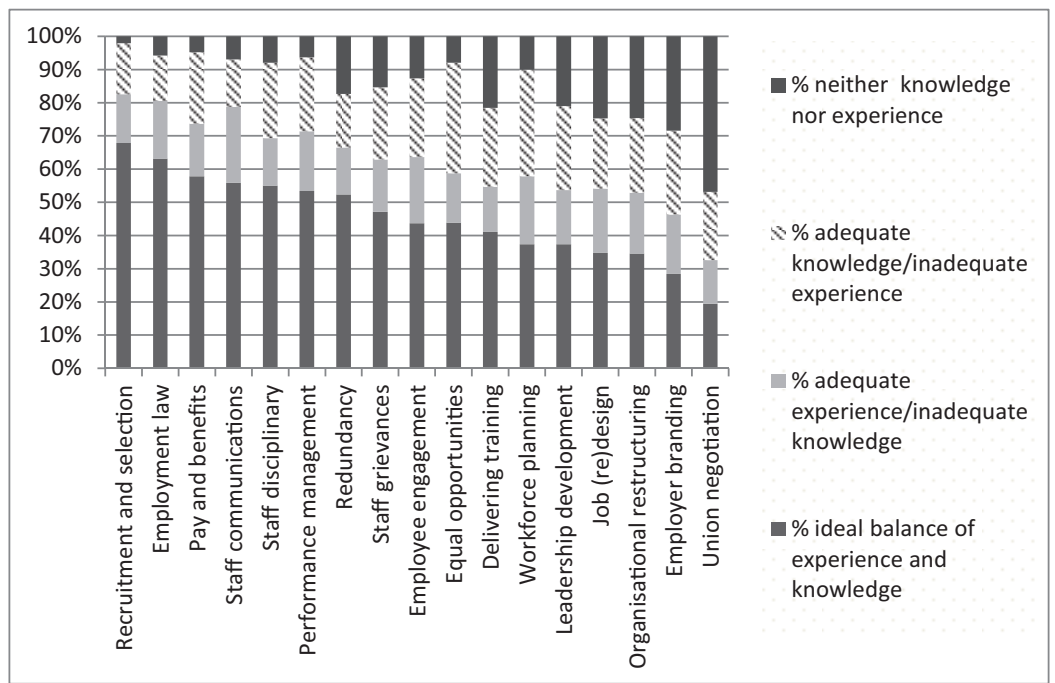

Figure 14.5 Balance of HR knowledge versus experience, HK respondents 


\section{Dilemma 4: Who is HRM For?}

In parallel with the developments described above, Kochan (2007) and Marchington (2015) have both warned that the shift in emphasis from a transactional to a strategic role has occurred in conjunction with a move to be seen as an agent exclusively for the benefit of employers. However, the position of HRM is complicated by the duality of roles that HRM managers have historically played as employer representatives and advocates for employee interests (Van Buren et al., 2011). Whilst the turn towards business 'strategic integration' and unitarism have, to a degree, curtailed the 'employee champion' or 'ethical gatekeeper' aspect of HR, these remain an important part of professional standards both in the UK and elsewhere (CIPD, 2012a; HKIHRM, 2000). Indeed, the CIPD is explicit that the 'courage to challenge' encompasses raising ethical and responsibility issues and also ensuring that employees with concerns are supported and protected (Parkes and Davis, 2013). The attempt to convey instrumental utility to managerially defined organizational objectives has led to a greater interest in the analytical tools being advocated for the purposes of promoting such issues as performance management. Thus, Spencer (2013: 346) identifies a 'threat' to more pluralistic approaches to HRM through the increasing influence of a 'narrow and regressive form of HRM' informed by neoclassical economic reductions of human behaviour. Similarly, Godard (2014) detects a process of individualization of employment relations practice, driven by the adoption of individualized metrics informed by unitarist-oriented organizational psychology.

Here, Van Buren et al. (2011: 211) suggest that HR may have a 'dark side as HRM professionals face pressure to eschew their traditional roles as employee champions in order to become accepted by others within their organizations as business partners'. This accompanies the further observation that HR is increasingly finding itself identified with strategies that once would have been seen as radical - like large-scale downsizing and the use of contingent workforces - but are now increasingly mainstream (Cavanaugh and Noe, 1999 in Van Buren et al. 2011). However, the evidence provided in the preceding section shows that fewer than 30 per cent of HR practitioners are involved in decisions concerning the outsourcing of in-house activity, which means that they may not necessarily be party to them.

Meanwhile, national-level interviews indicate broad support for the role of HR and the status of the relevant professional bodies. Despite general support there was interesting variation. Small business federations argued that HR professionals were excessively attached to an 'overprofessionalized' discourse which was difficult for small businesses 
to engage with, and at odds with 'business need'. They argued that professional services, such as employment law helplines, were a valuable source of information for small business, performing what was formerly a HR role, but that HR professionals themselves were inaccessible.

Within the case studies the greatest variation was in interviewees' views on the continued desirability of $\mathrm{HR}$ adopting the 'employee champion' role as part of its remit. Some managers and HR practitioners felt that it was important to distance HR from what was described as the 'frilly knickers' aspects of the role. Others, however, emphasized that the knowledge and skill set behind the employee relations aspect of HR practice was the most valued and irreducible aspect of the role - and this view came from private service sector non-unionized (albeit larger) workplaces and from operational managers as much as from HR practitioners. Such a view was based on a utilitarian rationale that curtailing the instincts of line managers on issues of conflict (grievances, discipline, performance) was important, so that consistency between managers could be achieved in order to prevent conflict situations spilling over to the external environment. Interestingly, when asked whether changes to regulatory constraints may shift the credibility of this external 'deterrent', respondents expressed that this employee relations advice had its own intrinsic value.

\section{CONCLUSION}

This chapter has identified HR as an emerging managerial profession. As a managerial profession its core commitment is to furthering organizational values over external professional codes of ethics. However, some scope for independence and discretion remains at the higher end of the occupational ladder, though this is partly explained by a fragmentation of $\mathrm{HR}$ at the lower end. In particular, the chapter identified separate groups of HR practitioners whose roles vary and do not necessarily require the performance of strategic functions. Moreover, such variety is increasingly reflected in the professional training that practitioners are provided with, and in their professional career ladders.

At the same time, some inspiration should be taken from the finding that when the professional membership standards are considered thematically, the role of HR 'professional' compared to, say, that of 'strategist' or 'technicist', is ranked highest amongst all participants from both economies. The professional theme includes such responsibilities as being required to ensure legal and regulatory compliance, and acting with integrity. Clearly on such institutional matters as law HR practitioners 
could be said to have a mandate, but the trickier predicament in their role ambiguity is how to extend this to ethical resilience. As Legge (1978) maintains, in a capitalist society dominated by the profit motive it is unlikely that managers will become powerful unless they learn to play by the 'rules of the game' (that is, demonstrate their strategic assets that they currently seem to lack as a whole; see Figure 14.1) or unless the 'rules' were somehow changed (that is, through their monitoring of institutional regulation as per legal matters, but also extending to some ethical regulation). An important implication of this is that, consistent with actual HR practice, the knowledge aspect of the professional standards content of both institutes could be bolstered to include new explicit material on ethics, independence and integrity, which currently exists only rather abstractly in their respective behaviour standards.

By strengthening members' formal HR knowledge in this way, HR associations can enhance their independent value by acting in the capacity of 'credible activist' or 'deviant innovator' for the industry. In this way certified members might be better prepared to lead the strategic influence of HR within their organizations, nurturing further expertise, trust and integrity for the entire profession. The associated challenge is to demonstrate how their expertise alone can fulfil such a role rather than being devolved to line managers and its message diluted.

The project to make East-West comparisons of HR competencies and practices has shown large overlaps between the skills and experience of HR practitioners in the UK and HK. Professional skills transcend national boundaries and cultural contexts, creating scope in the future for greater sharing of practice between HR practitioners and between the institutes that accredit and train them. Alternatively, if HRM moves away from the territory of a traditional profession and towards being a managerial profession, with its allegiance more closely tied to the firm than any set of professional standards or ethics, then such system responsibility may be more difficult to secure. At present, this study suggests that HR practitioners from both economies are less willing to challenge senior managers than middle managers and employees on HR issues.

In turn this begs the question: whose interest should HR be working for? Here, it would be unrealistic - given the basis of legitimacy for HR being organizational rather than occupational - to expect the HR practitioner to be a neutral arbiter in resolving competing interests between labour and capital. However, the scope for discretion, described above, does suggest an ethical gatekeeper role and evidence was presented to suggest that judgement should be exercized in reining in the excesses of 
managerial authority in some instances, particularly in areas framed around employment regulation.

Taken as a whole, then, the results suggest strengths in the issues around the broad areas of 'people resourcing', but lower levels of competence on issues of employee relations. Thus, there are strengths in individual aspects such as dealing with recruitment, employee performance and disciplinary issues, but knowledge gaps in the more collective issues of pay systems and union negotiation (which in $\mathrm{HK}$ is paralleled by 'staff communication' and 'engagement'). An outlier to all of this was the apparent gap in knowledge on the issue of employer branding and the implications of HR practice on external reputation.

The implications of the study for other established, new and emerging professions are manifold. Firstly, methodologically, it is possible to replicate this study's research method by conducting 'reality checks' of other professional practices vis-à-vis professional standards criteria. One section of the survey instrument used in this chapter was operationalized from the professional standards criteria of the CIPD and the HKIHRM. A similar research strategy could be deployed in other proportionate professions. Secondly, comparatively, if a useful proxy for professional status is exclusivity, then what of the form of HR professionalism in economies that have not seen an explosion in membership numbers as has the CIPD and to a lesser extent the HKIHRM? Thirdly, crossdisciplinarily, there is a further issue in the broader 'professionalization/ deprofessionalization' dynamic of other occupations - such as medicine, social work and teaching - which is that notwithstanding the wider social and structural dynamics at work, the agents of such dynamics inside an organization are likely to be the HR practitioners.

This chapter has examined four dilemmas concerning HRM as an emerging new managerial profession, intersecting the literature on both professions and HRM. For the literature on professions, the chapter has demonstrated how the status of professionalizing HR is predicated on a managerial source of power constructed within organizations rather than some necessary associational pursuit of closure. Along with nonlicensure, the traits of HRM remain an important indicator of the magnitude of associational impact, and obviously exert greater influence when manifested as institutionalization and mandate. For the literature on HRM, the chapter has more finely granulated the strategic versus administrative divide, acknowledging that HR practice varies considerably by certified status and organizational position. Further case study research is necessary, however, to capture the views and interactions of HR from other stakeholder perspectives, both within the organization and beyond. 


\section{ACKNOWLEDGEMENT}

The work described in this chapter was fully supported by a grant from the ESRC/RGC Joint Research Scheme sponsored by the Research Grants Council of Hong Kong and the Economic and Social Research Council of the United Kingdom (Project reference no. 9057004 RGC ref ES/J017299/1).

\section{REFERENCES}

Abbott, A. (1988). The System of Professions: An Essay on the Division of Expert Labour. Chicago, IL: University of Chicago Press.

Allen, M. and Wright, P. (2007). Strategic management and HRM. In Boxall, P., Purcell, J. and Wright, P. (eds), The Oxford Handbook of Human Resource Management. Oxford, Oxford University Press, pp. 88-107.

Bach, S. (2005). Personnel management in transition. In Bach, S. (ed.), Managing Human Resources, 4th edn. Oxford: Blackwell, pp. 3-44.

Bailey, M. (2011). Policy, professionalism, professionality and the development of HR practitioners in the UK. Journal of European Industrial Training, 35(5), 487-501.

Boxall, P. and Purcell, J. (2011). Strategy and Human Resource Management, 3rd edn. Basingstoke: Palgrave.

Brint, S.G. (1994). In an Age of Experts: The Changing Role of Professionals in Politics and Public Life. Princeton, NJ: Princeton University Press.

Brock, D.M., Leblebici, H. and Muzio, D. (2014). Understanding professionals and their workplaces: the mission of the Journal of Professions and Organization. Journal of Professions and Organization, 1(1): 1-15.

Brown, W. (1981). The Changing Contours of British Industrial Relations. A Survey of Manufacturing Industry. Oxford: Basil Blackwell.

Burrage, M. and Torstendahl, R. (eds) (1990). Professions in Theory and History: Rethinking the Study of the Professions. London: Sage.

Caldwell, R. (2003). The changing roles of personnel managers: old ambiguities, new uncertainties. Journal of Management Studies, 40(4): 983-1004.

Caldwell, R. and Purcell, J. (2007). The HR function: integration or fragmentation? In Purcell, J. (ed.), Human Resource Management: A Critical Text, 3rd edn. London: Thomson, pp. 21-38.

Carr-Saunders, A.M. and Wilson, P.A. (1933). The Professions. Oxford: Clarendon Press.

Cavanaugh, M. and Noe, R. (1999). Antecedents and consequences of relational components of the new psychological contract. Journal of Organizational Behavior, 20(3), 323-340.

CIPD (2010). Next Generation HR The Growth Option: Turbo-Charging HR's Impact in Asia. London: CIPD.

CIPD (2012a). HR Profession Map Our Professional Standards. London: CIPD.

CIPD (2012b). Code of Professional Conduct. London: CIPD. 
Dent, M. and Whitehead, S. (eds) (2002). Managing Professional Identities: Knowledge, Performativity and the 'New' Professional. London: Routledge.

DuGay, P. (1996). Consumption and Identity at Work. London: Sage.

Evetts, J. (1995). International professional associations: the new context for professional projects. Work, Employment and Society, 9(4): 763-772.

Evetts, J. (2006). Short note: the sociology of professional groups: new directions. Current Sociology, 54(1): 133-143.

Evetts, J. (2013). Professionalism: value and ideology. Current Sociology, 61(5-6): 778-796.

Exworthy, M. and Halford, S. (1999). Professionals and managers in a changing public sector: conflict, compromise and collaboration? In Exworthy, M. and Halford, S. (eds), Professionals and the New Managerialism in the Public Sector. Buckingham: Open University Press, pp. 1-17.

Fanning, B. (2011). Human resource management: the road to professionalization in the UK and USA. Unpublished Master's thesis, Kingston University, London.

Farndale, E. and Brewster, C. (2005). In search of legitimacy: personnel management associations worldwide. Human Resource Management Journal, 15(3), 33-48.

Flynn, R. (1999). Managerialism, professionalism and quasi markets. In M. Exworthy and S. Halford (eds), Professionals and the New Managerialism in the Public Sector. Buckingham: Open University Press, pp. 19-36.

Fox, A. (1966). Industrial Sociology and Industrial Relations. Research Paper 3, Royal Commission on Trade Unions and Employers Associations. London: HMSO.

Friedson, E. (1986). Professional Powers: A Study of the Institutionalisation of Formal Knowledge. Chicago, IL: University of Chicago Press.

Gilmore, S. and Williams, S. (2007). Conceptualising the 'personnel professional': a critical analysis of the Chartered Institute of Personnel and Development's professional qualification scheme. Personnel Review, 36(3): 398414.

Godard, J. (2014). The psychologisation of employment relations? Human Resource Management Journal, 24(1): 1-18.

Goffman, E. (1961). Asylums. Harmondsworth: Penguin Books.

Gold, J. and Bratton, J. (2003). The dynamics of professionalization: whither the HRM profession? Conference paper - Critical Management Studies 2003, Stream 8, Human Resource Management Phenomena - HRM and Beyond, Lancaster University, 7-9 July.

Greenwood, E. (1957). Attributes of a profession. Social Work, 2: 5-45.

Grey, C. (1998). On being a professional in a big six firm. Accounting, Organizations and Society, 23(5): 569-587.

Hall, P.A. and Soskice, D. (eds) (2001). Varieties of Capitalism: The Institutional Foundations of Comparative Advantage. Oxford: Oxford University Press.

Higgins, P., Roper, I. and Lo, M-F. (2014). Profiling the knowledge and behaviors of qualified HR practitioners in Hong Kong and the United Kingdom: results from an exploratory factor analysis. HRM and Professional Development in the Digital Age Conference 2014, 21 July. DOI: 10.5176/ 2251-2349_HRMPD14.15. 
HKIHRM (2000). Code of Conduct and Ethics for Human Resource Professionals. Hong Kong: HKIHRM.

Hofstede, G. (1984). Culture's Consequences: International Differences in Work-Related Values, Vol. 5. Thousand Oaks, CA: Sage.

Hope-Hailey, V., Farndale, E. and Truss, C. (2005). The HR department's role in organisational performance. Human Resource Management Journal, 15(3): 49-66.

Industrial Relations Services (2004). The changing shape of work how organizations restructure. IRS Employment Trends 794, London.

Kersley, B., Alpin, C., Forth, J., Bryson, A., Bewley, H., Dix, G. and Oxenbridge, S. (2005). Inside the Workplce. Findings from the 2004 Workplace Employment Relations Survey. London, Routledge.

Kochan, T.A. (2007). Social legitimacy of the HRM profession: A US perspective. In Boxall, P., Purcell, J. and Wright, P. (eds), The Oxford Handbook of Human Resource Management. Oxford: Oxford University Press, pp. 599619.

Larson, M.S. (1977). The Rise of Professionalism. Berkeley, CA: University of California Press.

Legge, K. (1978). Power, Innovation and Problem Solving in Personnel Management. London: McGraw-Hill

Legge, K. (2005). Human Resource Management. Rhetorics and Reality, Anniversary edition. Basingstoke: Palgrave.

Lengnick-Hall, M.L. and Aguinis, H. (2012). What is the value of human resource certification? A multi-level framework for research. Human Resource Management Review, 22(4), 246-257.

MacInnes, J. (1987). Thatcherism at Work. Industrial Relations and Industrial Change. Milton Keynes: Open University Press.

Marchington, M. (2015). Human resource management (HRM): too busy looking up to see where it is going longer term? Human Resource Management Review, http://dx.doi.org/10.1016/j.hrmr.2015.01.007.

Millward, N., Bryson, A. and Forth, J.A. (2000). All Change at Work? London: Routledge.

Muzio, D., and Kirkpatrick, I. (2011). Introduction: Professions and organizations - a conceptual framework. Current Sociology, 59(4): 389-405.

Muzio, D., Hodgson, D., Faulconbridge, J., Beaverstock, J. and Hall, S. (2011). Towards corporate professionalization: the case of project management, management consultancy and executive search. Current Sociology, 59(4): 443464.

Noordegraaf, M. (2011). Risky business: how professionals and professional fields (must) deal with organizational issues. Organization Studies, 32(10): 1349-1371.

Parkes, C. and Davis, A.J. (2013). Ethics and social responsibility - do HR professionals have the 'courage to challenge' or are they set to be permanent 'bystanders?' International Journal of Human Resource Management, 24(12): 2411-2434.

Parsons, T. (1939). The professions and social structure. Social Forces, 17: 457-467.

Columns Design XML Ltd / Job: Wilkinson-Perspectives_on_contemporary_professional_work / Division: 14-HRMprofessional_ts /Pg. Position: 26 / Date: 17/11 
Perkin, H. (2002). The Rise of Professional Society: England Since 1880. Abingdon: Routledge.

Pfadenhauer, M. (2006). Crisis or decline? Problems of legitimation and loss of trust in modern professionalism. Current Sociology, 54(4): 565-578.

Renwick, D. (2003). Line manager involvement in HRM: an inside view. Employee Relations, 25(3): 262-280.

Sanders, K. and Frenkel, S. (2011). HR-line management relations: characteristics and effects. International Journal of Human Resource Management, 22(8): 1611-1617.

Sciulli, D. (2005). Continental sociology of professions today: conceptual contributions. Current Sociology, 53(6): 915-942.

Spencer, D. (2013). Barbarians at the gate: a critical appraisal of the influence of economics on the field and practice of HRM. Human Resource Management Journal, 23(4): 346-359.

Streek, W. (2011). Taking capitalism seriously: towards an institutionalist approach to contemporary political economy. Socioeconomic Review, 9(1): 137-167.

Ulrich, D. (1998). A new mandate for human resources. Harvard Business Review, 76: 124-135.

Vaisey, S. (2006). Education and its discontents: overqualification in America, 1972-2002. Social Forces, 85(2): 835-864.

Van Buren III, H.J., Greenwood, M. and Sheehan, C. (2011). Strategic human resource management and the decline of employee focus. Human Resource Management Review, 21(3): 209-219.

Van Wanrooy, B., Bewley, H., Bryson, A., Forth, J., Freeth, S., Stokes, L. and Wood, S. (2013). Employment Relations in the Shadow of Recession: Findings from the 2011 Workplace Employment Relations Study. Basingstoke: Palgrave Macmillan.

Weber, M. (1978). Economy and Society: An Outline of Interpretive Sociology, 2 vols, Guenther Roth and Claus Wittich (eds). Berkeley, CA: University of California Press.

Wiley, C. (1995). Reexamining professional certification in human resource management. Human Resource Management, 34(2): 269-289.

Wright, C. (2008). Reinventing human resource management: business partners, internal consultants and the limits to professionalization. Human Relations, 61(8): 1063-1086.

Yuan, L. (2013). Traditional Chinese Thinking on HRM Practices: Heritage and Transformation in China. Basingstoke: Palgrave Macmillan. 